\title{
Development and Test of On-line Cyber Crime Survey System for Manado
}

\author{
Anthon Arie Kimbal, Harson Kapoh, Josephin Sundah \\ Dept. of Informatic Engineering \\ Manado State Polytechnic \\ Manado 95252 North Sulawesi \\ Indonesia
}

\begin{abstract}
Current cybercrime or cybercrime is very alarming. This study was conducted because more and more people who have cases that belong to cybercrime. According to preliminary data, cybercrime has occurred in the city of Manado. The city of Manado as the capital of North Sulawesi province has also been a victim of crime from cyberspace. What kind of cybercrime is experienced by the people of Manado City who want to be traced in this research by developing online survey system that can be used to get the cybercrime information quickly, accurately and accurately? By using waterfall system development method then designed an online based survey system and performed performance testing of system functionality that was built with the help of scale linker 1-5 to help calculate the percentage of respondents' answers. The result of this research can be an online based survey system to obtain information characteristic cybercrime experienced by Manado city residents and the results of system testing with data analysis as much as $73.33 \%$ of respondents stated that the application is easy to use, $56.66 \%$ respondents stated that survey questions are easy to understand and $70 \%$ of respondents stated that the application is appropriate for the survey.
\end{abstract}

\section{Keywords}

System, survey, testing, cybercrime.

\section{INTRODUCTION}

Manado as a developing city in Indonesia got the impact of technological developments, especially internet. The ease provided by this internet technology raises a new phenomenon for modern society. This makes the way people live in different areas of life both positively and negatively.

Cybercrime is now one of the negative phenomena and a place for the development of a crime. Where more and more crimes are exploiting the pace of emerging modern technology and offering to commit crime as well as criminal activity through social media and the internet. As well as in written attacks on social media that is defamation, as well as attacks such as identity theft, and fraud via sms. Because at this time the development of informatics technology has been very rapid and global and bring a very significant impact in human life.

The real crime now begins to grow and flourish in society, there is no evil without the people who make it. We know a lot about the various crime factors that exist in society, but what is certain is that evil is one form of human behavior that continues to develop parallel with the development of society itself [1].

Various crimes often occur with the development of information technology, as well as money laundering crime is often done through the internet, in this case the abuse of internet banking facilities. The nature of money laundering becomes universal and transnational in that it crosses the boundaries of state jurisdiction [3]. This means that the understanding of criminal law against this crime is no longer related to the territorial principle of a country but more than one national law is violated. The proceeds of this criminal act shall not only be stored or utilized in a financial institution of a country of origin, but may also be transferred to another country by various means and interests, for example by means of electronic cyberpayment payment [4] This kind of activity involves more than one national criminal law. Bank Indonesia states that criminal acts of bribery, corruption, gambling, counterfeiting money are the triggers of money laundering. Money Laundering can lead to distrust of customers and society to the banking system.

Science in the field of information technology, especially to process electronic data is growing. According Jogiyanto (2005), information system development methodology has been very good since the early 1970 s so to develop the information model becomes easier. Many organizations today are starting and already implementing information technology because the reality of information technology can help in decision making, planning and transactions quickly, accurately and relevant (Raymond McLeod Jr \& George Schell, 2004).

Internet technology is increasingly growing both capacity and speed. The Internet, which is a vast network, is a necessary and essential information medium for human and organizational needs [12]. With internet people can enter data and get information quickly, precisely and accurately. To obtain information can be done in many ways. One of them is to conduct a survey. With the survey information can be collected through a sample representing the population [10].

In this research, the development of survey based on line and analyze the system successfully developed by doing performance test to the system. This on-line survey is intended to find out the types of cybercrime that is experienced by the people of Manado City.

\section{TEORY}

\subsection{Survey}

Survey is information collected from respondent by using questionnaire or questionnaire. The definition of the survey is also limited to the research with the data collected from the sample or population so that the survey research is a study by taking samples from the population to be studied by using questionnaires as a data collection tool [10]. 


\subsection{On-Line survey}

Online survey is one way of collecting data in the survey. Many advantages when using online surveys. Such as improving system function in conducting surveys that have been there [10].

\section{RESEARCH METODOLOGI}

\subsection{Stage of Research}

This research is used using stages as in Figure 1.

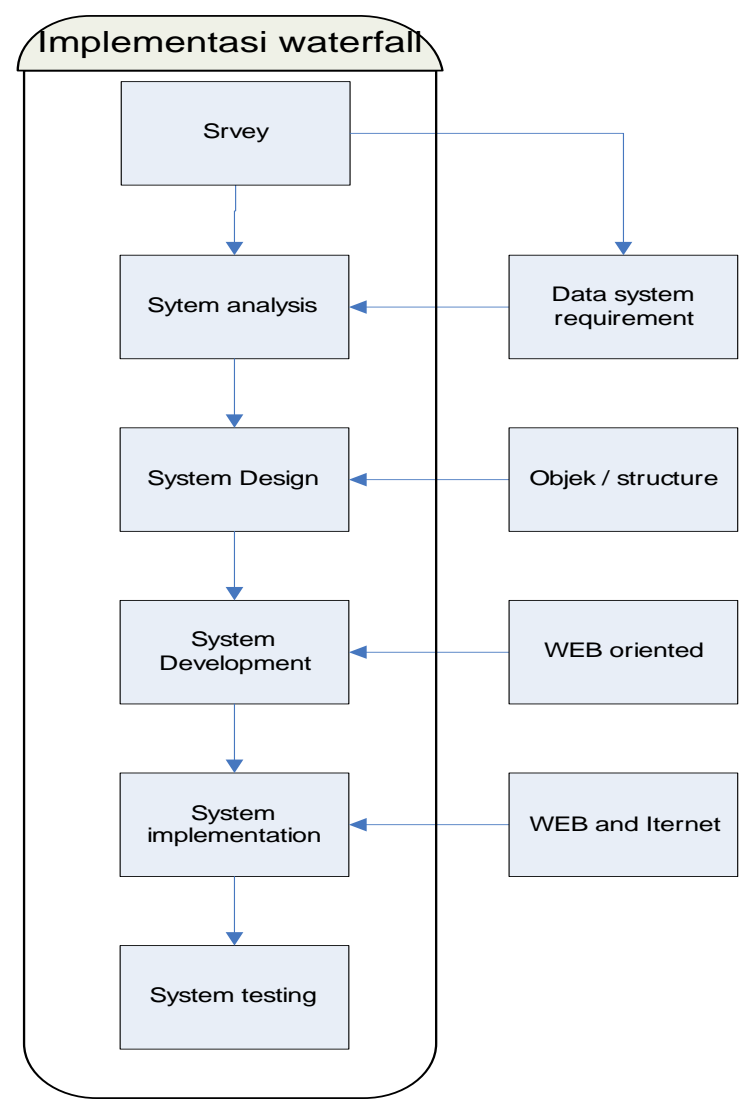

Fig 1 : Block State of research

Figure 1. is a block diagram illustrating the research phases that are sadur and modified from the waterfall method [9].

\subsection{Research Methods}

The methods used for this study is

- Methods of field studies (observation study) and literature (library study). This method is used to identify the problem.

- Interview method, used to determine the system to be built [6].

- Questionnaire method, used to determine the level of Employee participation in providing information [6].

- Method of architecture is the method that will be used to describe the system[9].

- Functional testing using black box to see the results when the system is run if the system can receive data, whether the server is responding and displays information in accordance with the reality on the ground[9].
- Evaluate the interface using respondents with a questionnaire to test the performance whether the system easy to use[9].

\subsection{Design of Research}

The study design consists of:

- Literature review

- Studies conducted to collect the reference to be used as the material resources that include: hand books, journals, papers / articles and previous studies associated with the system will design and applied

- Analysis, design and implementation of applications.

- Analysis of system performance.

- Preparation of reports

\section{IMPLEMENTATION}

\subsection{Architecture Model}

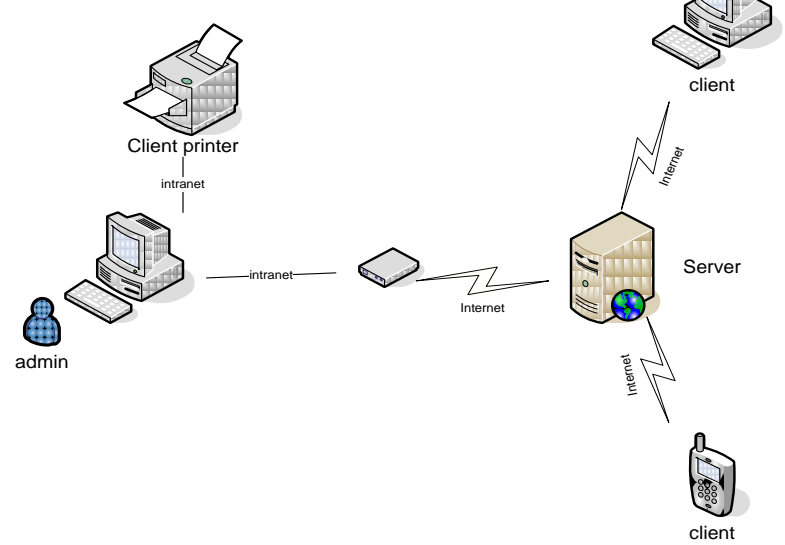

Fig 2: Design of architecture model

Figure 2. illustrates the architecture of an online survey model consisting of a server for storing data, admin controlled and accessible via PC, laptop, or smartphone via the internet network.

\subsection{Use Case}

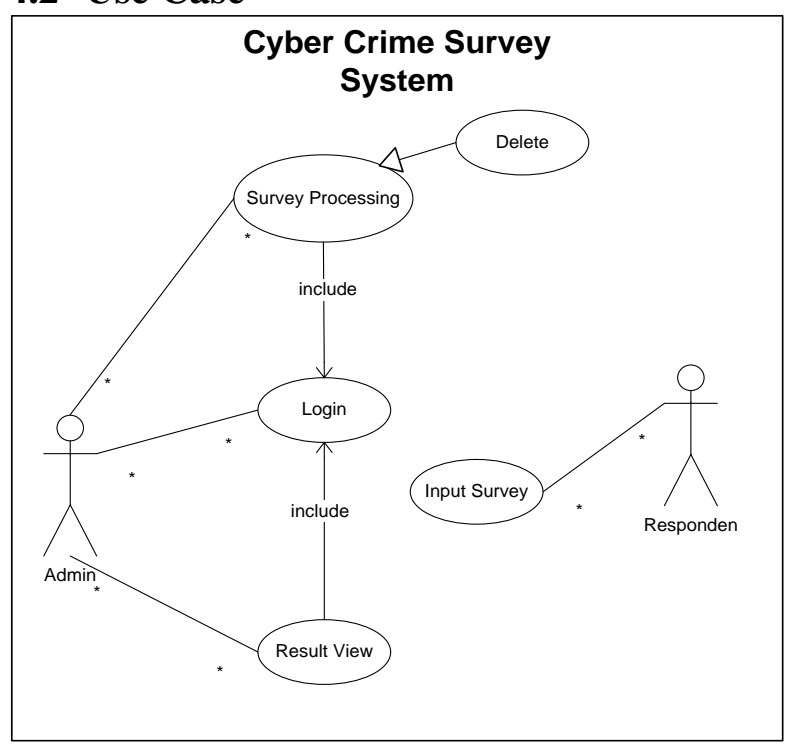

Fig 3: Use case survey 
Figure 3. is the required functionality design of the developed model consisting of login, survey processing, and survey viewing and filling out survey questions.

In the function of survey acquisition there is a delete function that can be used by admin to delete survey data that is no longer needed.

In this use case design admin can access the Processing survey, see the results of the survey by first logging in and the user will be able to access the function of charging survey without having to login.

\subsection{Activity Diagram}

An Activity diagram is a diagram to help design the activity flow of the system being designed.

Figure 4. illustrates the activity flow design of the survey system. Activity survey system in begin from admin who do login and send survey question then user or respondent do activity of filling according to existing question And send back answer through internet network. The results of charging by the respondent can be seen by the admin and admin can get out of the system when it is finished work.

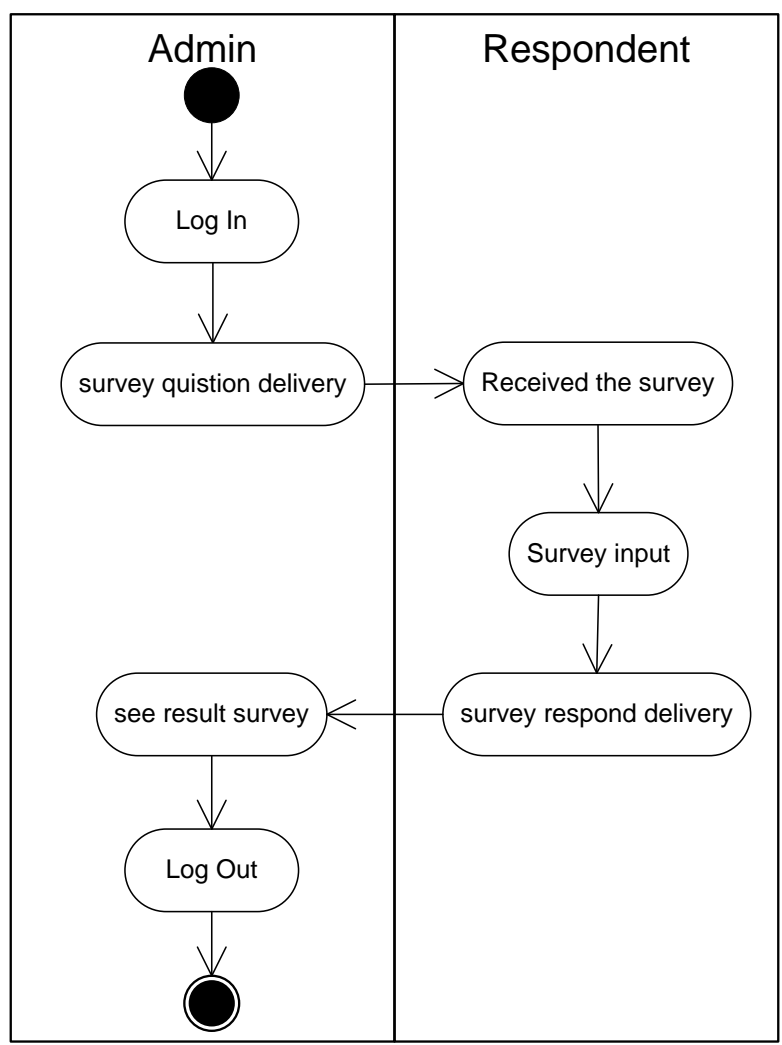

Fig 4: Activity diagram

\subsection{Interface}

The interface of the survey system is divided into 2 namely the admin and the user as a respondent who filled the survey.

\subsubsection{Login Interface}

Figure 5. is the initial view of the survey system. In this view there is a login form used to access the system.

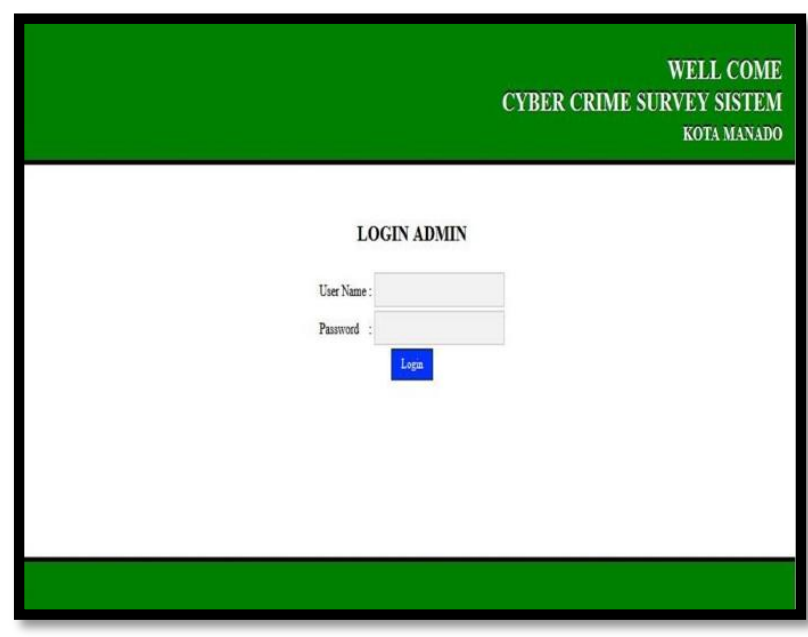

Fig 5: Login

\subsubsection{Admin interface}

Figure 6 . is the interface when the admin has entered the password and username correctly.

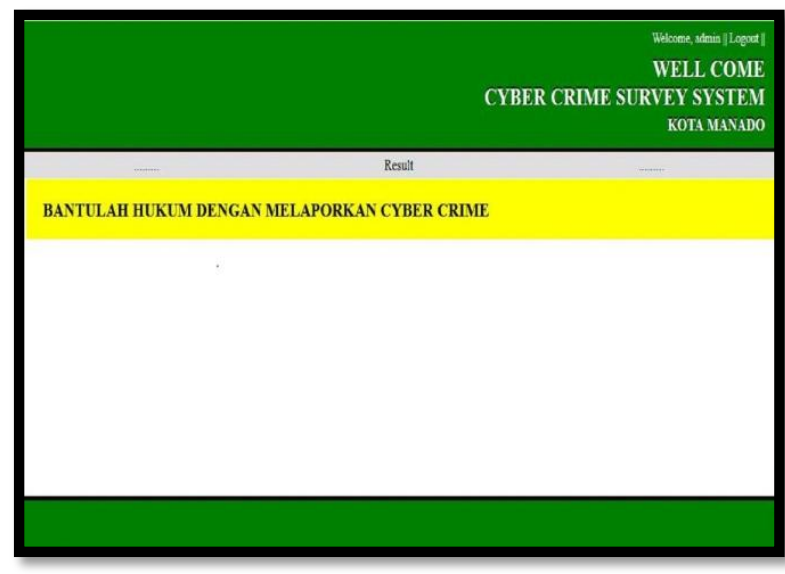

Fig 6: Homepage

\subsubsection{Result interface}

Figure 7. is the system interface used to view the survey results in the form of a table based on questions given to the respondent.

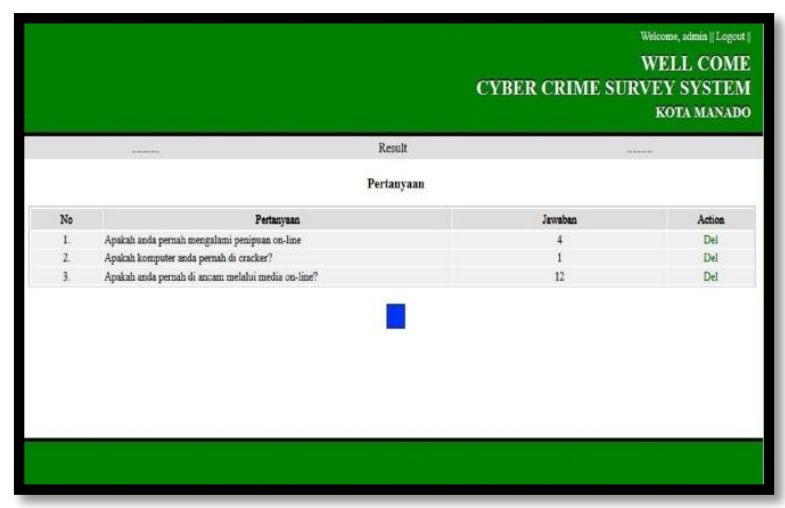

Fig 7: Result 


\section{TESTING}

The data used for the test is the result of system testing from the user or the respondent is the student. They are asked to try the system and answer questions relating to the look of the system or application. This performance test to determine whether the functional system can be understood by the user [11]. Tests have been conducted on 30 users as respondents with the results as in table 1 . Model questions and calculations follow the research that has been done by [11]

Table 1. Result

\begin{tabular}{|c|c|c|c|c|c|c|}
\hline \multirow{2}{*}{ No } & \multirow{2}{*}{ Question } & \multicolumn{5}{|c|}{ Answer Score } \\
\hline & & 5 & 4 & 3 & 2 & 1 \\
\hline 1 & $\begin{array}{l}\text { Is this } \\
\text { application } \\
\text { easy to use? }\end{array}$ & 22 & 3 & 5 & & \\
\hline 2 & $\begin{array}{l}\text { Is the survey } \\
\text { question on } \\
\text { this system } \\
\text { easy to } \\
\text { understand? }\end{array}$ & 17 & 1 & 2 & 10 & \\
\hline 3 & $\begin{array}{ll}\text { Is this app } \\
\text { suitable for } \\
\text { survey }\end{array}$ & 21 & 5 & 4 & & \\
\hline
\end{tabular}

Table 1. shows the score of the respondent's answer after calculated then then sought percentage. The Liker scale is used to calculate answers from users or respondents [11], with each answer given a score of 1-5 with the following explanation:

1. Strongly Disagree $(\mathrm{STS})=1$

2. Disagree $(\mathrm{TS})=2$

3. Simply Agree $(\mathrm{CS})=3$

4. Agree $(S)=4$

5. Strongly Agree $(\mathrm{SS})=5$

The results of data analysis for question 1 shows as many as $73.33 \%$ of respondents stated that this application is easy to use. For question 2 shows as many as $56.66 \%$ of respondents stated that survey questions are easy to understand. For statement 3 shows as many as $70 \%$ of respondents stated that the application is appropriate for the survey.

\section{CONCLUSION}

System development through design resulted system with admin and user which have been done to get on-line based survey system and with the result of assessment for testing using 30 responders using scale of linker 1-5 got that first question indicate as much as $73,33 \%$ of respondents stated that application this is easy to use. For the second question shows $56.66 \%$ of respondents stated that survey questions are easy to understand. For the third statement shows as many as $70 \%$ of respondents stated that the application is appropriate for the survey. All three answers are on a scale of 5 is strongly agree. Based on the results of this web application performance test is feasible to be used for the survey then the future will be implemented to find out a cybercrime characteristic data that occurs in the city of Manado North Sulawesi Indonesia by obtaining data from the community with them fill out the survey online. The collected data is expected to help determine the system, policies and laws prevailing in Indonesia that are related to cybercrime.

\section{ACKNOWLEDGMENTS}

Thanks to the Manado State Polytechnic Leadership, Center for Research and friends who have helped.

\section{REFERENCES}

[1] Agus Raharjo, 2002, Cybercrime Pemahaman dan Upaya Pencegahan Kejahatan Berteknologi, Bandung, hal.29

[2] Budi Agus Riswandi, Aspek Hukum Internet Banking, PT Raja Grafindo Persada, Jakarta, 2005, hlm. 186.

[3] Munir Fuady.. Hukum Perbankan Indonesia. Cirtra Aditya Bakti, Bandung. 2001. hlm. 154.

[4] NHT. Siahaan.. Pencucian uang dan Kejahatan Perbankan. Sinar Harapan. Jakarta, 2005, hlm. 103.

[5] Direktorat penelitian dan pengabdian pada masyarakat, 2013., Panduan pelaksanaan penelitian dan pengabdian pada masyarakat di perguruan tinggi

[6] Jogiyanto., 2005, Analisis dan Disain Sistem, Penerbit Andi

[7] McLeod Raymond Jr., Scell G d, 2004, Sistem Informasi Manajemen, Prentice Hall, New Jersey, (terjemahan)

[8] Pusat Bahasa, 2008, situs resmi Kamus Besar Bahasa Indonesia,http://badanbahasa.kemdiknas.go.id. Tanggal akses 10 April 2015 pada pukul 21.00.

[9] Rosa., Shalahudin., 2011,Rekayasa Perangkat Lunak, Penerbit Modula, Bandung

[10] Burhan M, (2009) Kuantitative Research Metodology. Jakarta. Kencana

[11] Melo, O., Tanod, T., \& Tangkudung, R. 2016. Model Show Window for Raising Chrisanthenum Kulo and Riri based Information Technology as Tourism Destination in Town of Tomohon. International Journal of Computer Applications, 155(2)

[12] Kapoh, H., Doringin, F., \& Taju, M. M. 2016. Design and Development of the Public Service Information: A Case Study of Villages in District East Tombariri, Minahasa-Indonesia. International Journal of Computer Applications, 156(12). 